\title{
Restriction fragment analysis of the ribosomal DNA of Paratelmatobius and Scythrophrys species (Anura, Leptodactylidae)
}

\author{
Luciana B. Lourenço ${ }^{1}$, Paulo C.A. Garcia ${ }^{2}$ and Shirlei M. Recco-Pimentel ${ }^{1}$ \\ ${ }^{1}$ Departamento de Biologia Celular, Instituto de Biologia, Universidade Estadual de Campinas \\ (UNICAMP), Campinas, SP, Brazil. \\ ${ }^{2}$ Instituto de Biociências, Universidade Estadual Paulista (UNESP), Rio Claro, SP, Brazil.
}

\begin{abstract}
Physical maps of the ribosomal RNA gene $28 \mathrm{~S}$ of species belonging to the genera Paratelmatobius and Scythrophrys were constructed, using five restriction endonucleases. The restriction sites for Bam $\mathrm{HI}, B g / \mathrm{II}, B s t$ EII, and Eco RI had similar positions in all species, although there were interspecific differences in the size of the restriction fragments obtained. An additional Pvull site was found in Scythrophrys specimens from Piraquara (State of Paraná, Brazil) and from São Bento do Sul (State of Santa Catarina, Brazil), but not in the Scythrophrys specimens from Rancho Queimado (State of Santa Catarina, Brazil). This finding is in agreement with the hypothesis regarding the existence of two species in the genus Scythrophrys. On the other hand, the extra Bst Ell site considered in the literature to be a synapomorphy for the subfamilies Leptodactylinae and Telmatobiinae was not observed in the genera Paratelmatobius and Scythrophrys, which brings new questions about some taxonomic classifications that include Paratelmatobius in Leptodactylinae and Scythrophrys in Telmatobiinae. Interspecific variation was observed in the size of the restriction fragments analyzed and, in the case of group I Scythrophrys, there was also a variation between the individuals of the two populations. These data suggest that sequencing of the rDNA segments studied here may be useful in phylogenetic studies of the genera Paratelmatobius and Scythrophrys.
\end{abstract}

Key words: ribosomal DNA, 28S rDNA gene, restriction sites, physical map, Paratelmatobius, Scythrophrys, Leptodactylidae, Anura.

Received: July 15, 2002; accepted: March 10, 2003.

\section{Introduction}

The nuclear ribosomal DNA (rDNA) in the NOR (nucleolar organizer regions) of eukaryotes consists of tandemly repeated copies of the transcriptional unit for the precursor of $18 \mathrm{~S}, 5.8 \mathrm{~S}$, and $28 \mathrm{~S}$ ribosomal RNA (rRNA), separated by an intergenic spacer (IGS). Two internal transcribed spacers, known as ITS 1 and ITS 2, are located between the regions coding for $18 \mathrm{~S}$ and $5.8 \mathrm{~S}$ rRNA, and between the latter and the $28 \mathrm{~S}$ coding region. In addition, an external transcribed spacer (ETS) occurs upstream to the 18S gene (Long and Dawid, 1980; Miller, 1981). The copies of rDNA genes in a species evolve in concert through coordinated mechanisms (Arnheim et al., 1980; Dover and Coen, 1981; Krystal et al., 1981; Coen et al., 1982a,b; Arnheim, 1983). As a result, intra- and interindividual variations in rDNA are small and, when present, affect particularly the intergenic spacer (see Hillis and Dixon 1991 for a review).

The low rate of polymorphism in the rDNA transcription unit allows characterization of the rDNA of each spe-

Send correspondence to L.B.L. E-mail: bolsoni@ hotmail.com. cies using only a few specimens, and makes this DNA useful for interspecific comparisons. In addition, the different coding regions of the rDNA repeats usually show distinct evolution rates. As a result, this DNA can provide information about almost any systematic level (see Hillis and Dixon, 1991).

In anurans, restriction mapping of the $28 \mathrm{~S}$ gene in 54 species identified regions of variability that could be useful in phylogenetic studies (Hillis and Davis, 1987). Additionally, an interesting Bst EII site was reported by Hillis and Davis (1987) as a possible synapomorphy for the leptodactylid subfamilies Leptodactylinae and Telmatobiinae, as they are considered by Duellman and Trueb (1986).

The leptodactylid genera Paratelmatobius and Scythrophrys are closely related, as suggested by morphological, ecological (Lynch, 1971; Heyer, 1975; Garcia, 1996) and cytogenetical (Lourenço et al., in press) data. However, many authors have considered them as belonging to two different subfamilies, Leptodactylinae and Telmatobiinae, respectively (see Lynch, 1971; Duellman and Trueb, 1986; Frost, 2000). According to the most recent 
taxonomic review of amphibians, both Paratelmatobius and Scythrophrys belong to the same subfamily, named Cycloramphinae (Frost, 2002). Actually, the taxonomic relationships of Paratelmatobius and Scythrophrys with other leptodactylids are still not clear, and further data are needed for their correct allocation in subfamilies.

The available information about Paratelmatobius and Scythrophrys includes cytogenetic analyses showing interspecific variation in the NOR location in three karyotypes of Paratelmatobius (Lourenço et al., 2000; Lourenço et al., 2003) and two of Scythrophrys (Lourenço et al, in press). However, the organization of the rDNA genes in these genera is not known yet.

In this paper, we present a preliminary analysis of the $28 \mathrm{~S}$ ribosomal RNA gene in Paratelmatobius and Scythrophrys.

\section{Materials and Methods}

\section{Specimens}

Three Paratelmatobius poecilogaster specimens, four Paratelmatobius cardosoi, four Paratelmatobius sp (aff. cardosoi) (see Lourenço et al, 2003), eight Scythrophrys from the karyotype group I (five from Piraquara, State of Paraná, and three from São Bento do Sul, State of Santa Catarina, Brazil), and six Scythrophrys specimens from the karyotype group II (from Rancho Queimado, State of Santa Catarina, Brazil) (see Lourenço et $a l$, in press) were studied. The $P$. poecilogaster and $P$. cardosoi specimens were collected at Paranapiacaba (State of São Paulo, Brazil), and the Paratelmatobius sp (aff. cardosoi) specimens came from Piraquara (State of Paraná, Brazil). For comparison, specimens of two Cycloramphinae genera (sensu Frost, 2002), Cycloramphus izecksohni (previously in the subfamily Leptodactylinae) (one specimen from Corupá, State of Santa Catarina, Brazil) and Hylodes asper (previously in the subfamily Hylodinae) (one specimen from Paranapiacaba) were also used. All the specimens studied were deposited at the Célio F.B. Haddad collection (CFBH), Departament of Zoology, Universidade Estadual Paulista, Rio Claro, SP, Brazil, and at the "Prof. Adão José Cardoso" Museum of Natural History (ZUEC), Universidade Estadual de Campinas, Campinas, SP, Brazil.

\section{Southern blot}

Genomic DNA was extracted from fresh or frozen liver and muscle tissue, using a standard phenol/chloroform method (Sambrook et al., 1989). About 1-2 $\mu \mathrm{g}$ of genomic DNA from each specimen were digested with the restriction enzymes Eco RI, Bam HI, Bgl II, Bst EII, and Pvu II, used singly or in combination. The resulting fragments were separated on $1.2 \%$ agarose gels at about $1.5 \mathrm{~V} / \mathrm{cm}$ in $1 \mathrm{x}$ TBE, and transferred onto positively charged nylon membranes (Hybond) (Sambrook et al., 1989).

\section{$28 \mathrm{~S}$ rDNA probe}

An Eco RI-Bam HI fragment $(\sim 2,5 \mathrm{~kb})$ of the Xenopus laevis 28S gene extracted from the plasmid HM 123 (Meunier-Rotival et al., 1979) was subcloned into the phagemid pBlueScript (pBS 28) (Figure 1) and used as probe, after labeling with digoxigenin by the random primer method, according to the manufacturer's instructions (Boehringer Mannheim).

\section{Hybridization}

The membranes were pre-hybridized for $2-3 \mathrm{~h}$ in $5 \mathrm{x}$ SSC, $50 \%$ formamide, $0.1 \%$ lauroylsarcosine, $0.02 \%$ SDS, and $2 \%$ blocking reagent (Boehringer Mannheim), and then hybridized overnight with the pBS 28 probe, at $42{ }^{\circ} \mathrm{C}$ in pre-hybridization solution. After hybridization, the membranes were washed twice in 2x SSC and $0.1 \%$ SDS solution at room temperature, and twice in $0.1 \times \mathrm{SSC}$ and $0.1 \%$ SDS solution at $60{ }^{\circ} \mathrm{C}$. Each wash lasted $15 \mathrm{~min}$. The probe was detected by using a chemiluminescence system from Boehringer Mannheim, with CSPD as the chemiluminescent substrate. After incubation with the substrate, the membranes were exposed to X-ray films (Hyperfilm ECL, Amersham). The bands were documented, and the length of the restriction fragments was inferred using a Kodak Digital Science System.

\section{Results}

Restriction site maps of the $28 \mathrm{~S}$ ribosomal gene were constructed for $P$. poecilogaster, $P$. cardosoi, Paratelmatobius sp (aff. cardosoi), and for three Scythrophrys populations (Figure 2). The restriction sites for Bam HI, Bgl II, Bst EII and Eco RI had similar positions in all species, although there were interspecific differences in the size of the restriction fragments obtained (Figures 2-4). The digestions using $P v u$ II showed that the individuals from the two group I Scythrophrys populations had an extra site for this enzyme, that was absent in the Scythrophrys specimens from Rancho Queimado and in the other species analyzed. Hylodes asper had three $P v u$ II sites (Figures 5 and 6).

Weak bands were detected after double digestion with $B g l$ II and $P v u$ II, and were considered to be the product of partial digestions (Figure 5). This conclusion agreed with the pattern obtained in other experiments and by some

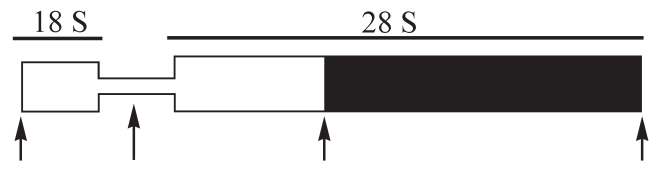

Figure 1 - Representation of the Xenopus laevis rDNA fragment in the plasmid HM 123 (Meunier-Rotival et al., 1979). The arrows and arrowheads indicate the restriction sites of Eco RI and Bam HI, respectively. The solid block represents the fragment of about $2.5 \mathrm{~kb}$ subcloned in pBueScript and used as probe. 


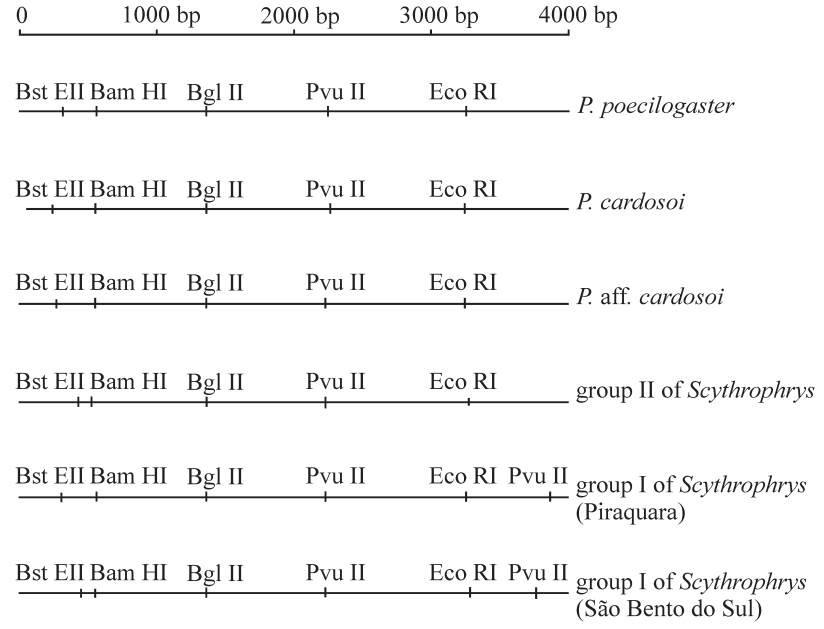

Figure 2 - Restriction maps of Paratelmatobius and Scythrophrys 28S rDNA for the enzymes Bst EII, Bam HI, Bgl II, Pvu II and Eco RI. (The presumed $P v u$ II site of Scythrophrys from group II experiments is not shown).

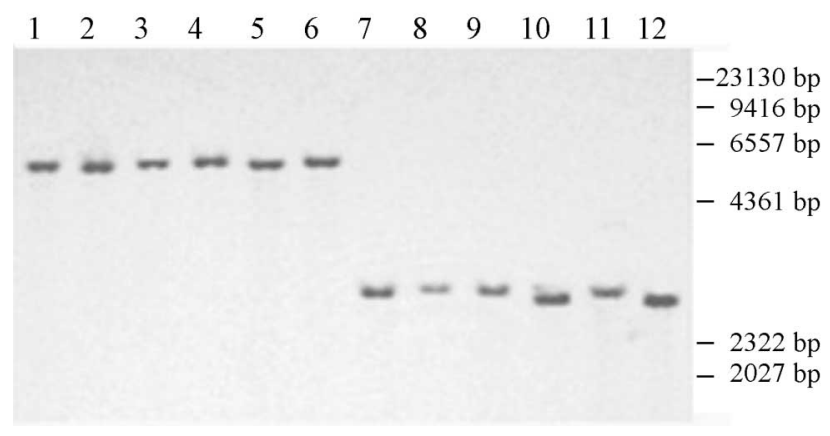

Figure 3 - Fragments of genomic DNA obtained after digestion with Eco RI (1-6) and Eco RI-Bst EII (7-12) and hybridization with the pBS 28 probe. 1-2, 7. Paratelmatobius poecilogaster. Lanes 1 and 2 contain DNA from two individuals, both of which showed the same pattern. 3, 8. $P$. cardosoi. 4, 9. Paratelmatobius sp (aff. cardosoi). 5, 11. Scythrophrys of group I from Piraquara. 6, 12. Scythrophrys of group I from São Bento do Sul. 10. Scythrophrys of group II from Rancho Queimado.

single digestions not shown here. Comparison of these data with the restriction sites in the rDNA sequence of Xenopus laevis (GenBank/X02995) indicated that the $\sim 1 \mathrm{~kb}$ fragment in lanes 1 and 5 of Figure 5 was a $B g l$ II- $P v u$ II segment derived from partial digestion of $P v u$ II, since this hypothetical site is present in $X$. laevis. The total digestion of this fragment probably gave rise to two fragments, one of $\sim 900 \mathrm{bp}$ and another of about $100 \mathrm{bp}$, not detected in our hybridization experiments. Since partial digestions were not done for all of the species studied, the hypothetical $P v u$ II site mentioned above was not considered in interspecific comparisons.

There was no intraindividual or intrapopulational variation either in the number or in the size of the fragments generated in any of the experiments (Figures 3-6 and data not shown). In contrast, an interpopulational variation was

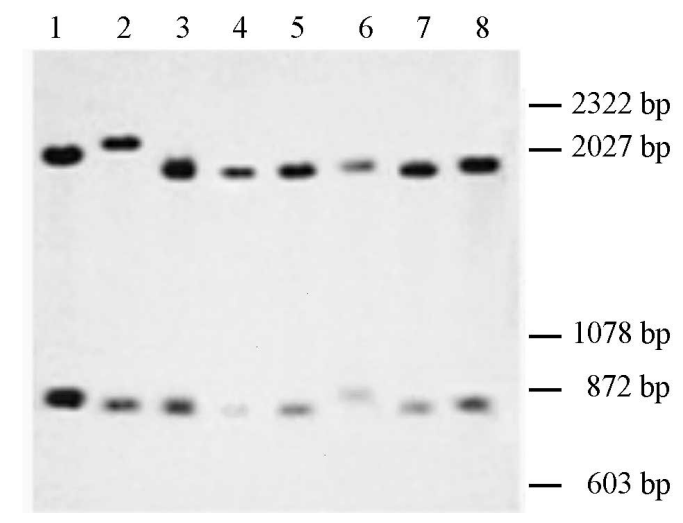

Figure 4 - Fragments of genomic DNA from Hylodes asper (1), Cycloramphus izechsoni (2), Paratelmatobius poecilogaster (3), P. cardosoi (4), Paratelmatobius sp (aff. cardosoi) (5), Scythrophrys from Rancho Queimado (6), Scythrophrys of group I from Piraquara (7), and of group I from São Bento do Sul (8) hybridized with the pBS 28 probe, after digestion with Eco RI-Bam HI-Bgl II.

observed in the size of the digested fragments of Scythrophrys group I (Figure 3: lanes 10-12; Figure 4: lanes 6-8; Figure 5: lanes 5-7). Interspecific variation in the size of the digested fragments was also found. The three Paratelmatobius species, for example, could easily be distinguished from each other by variations in the size of the $B g l$ II- $P v u$ II fragment (Figure 5: lanes 2-4) and of the Bst EII-Bam HI fragment (Figure 2), whose size was inferred from the analysis of the experiments shown in Figures 3 (lanes 7-9) and 4 (lanes 3-5).

\section{Discussion}

The restriction sites of Bam HI, Bgl II, and Eco RI found in all the specimens studied here were also detected in the anurans analyzed by Hillis and Davis (1987). The same applies to the $P v u$ II site located between the $B g l$ II and the Eco RI sites. On the other hand, the Bst EII site observed in all Paratelmatobius and Scythrophrys species was absent in some of the anurans investigated by Hillis and Davis, although it was present in the three leptodactylids analyzed by them (Ceratophrys ornata, Leptodactylus wagneri and Telmatobius niger).

Moreover, Hillis and Davis (1987) detected an interesting extra Bst EII site between the $B g l$ II and the $P v u$ II sites mentioned earlier. It was found only in the leptodactyline Leptodactylus wagneri and in the telmatobine Telmatobius niger and was therefore considered to be a possible synapomorphy for these Leptodactylidae subfamilies. None of the Paratelmatobius and Scythrophrys species studied here had this extra Bst EII site. So, if we consider the classification adopted by Duellman and Trueb (1986) and followed by Hillis and Davis (1987), our results refute the hypothesis of Hillis and Davis about the interpretation of the extra Bst EII site, since, by that classification, Scythrophrys belonged to the 


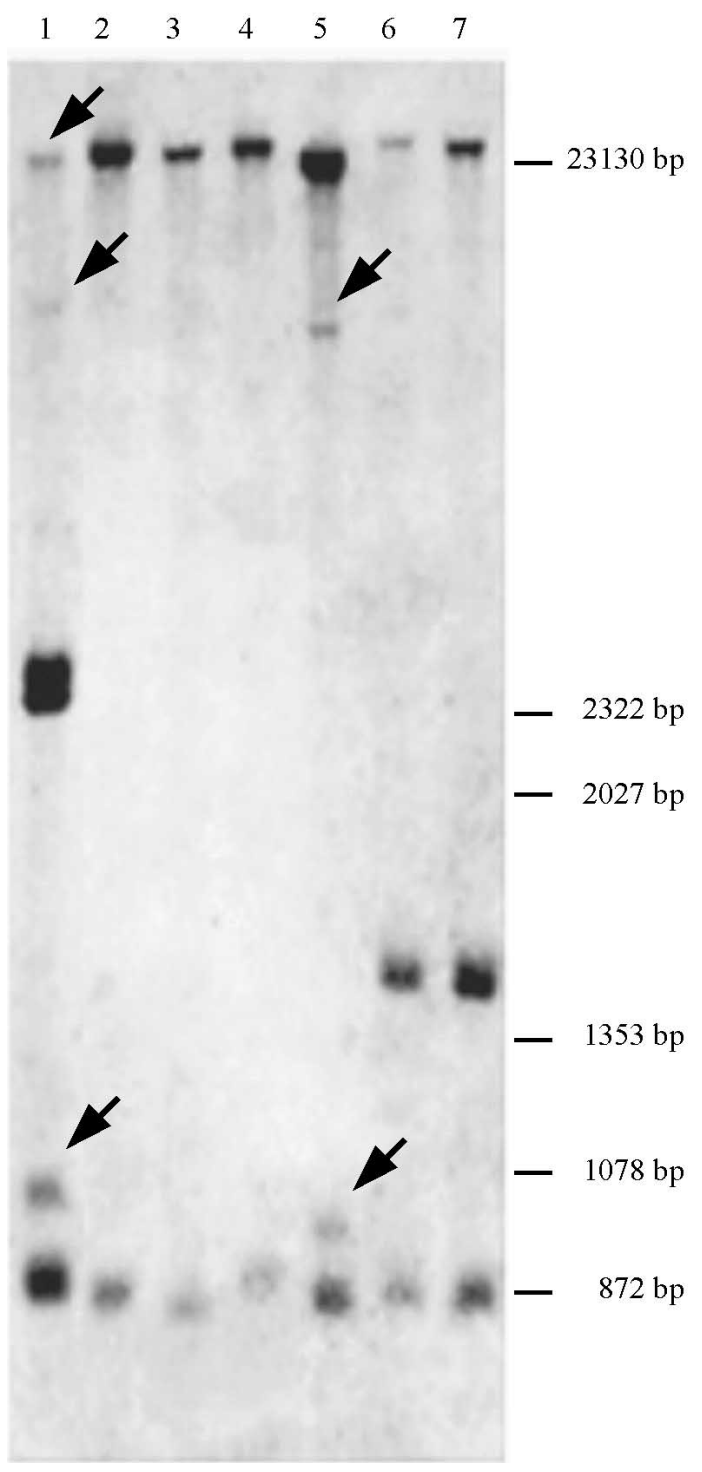

Figure 5 - Southern blotting of the genomic DNA of Hylodes asper (1), Paratelmatobius poecilogaster (2), P. cardosoi (3), Paratelmatobius sp (aff. cardosoi) (4), Scythrophrys from Rancho Queimado (5), Scythrophrys of group I from Piraquara (6), and Scythrophrys of group I from São Bento do Sul (7) with the pBS 28 probe, after double digestion with $B g l \mathrm{II}$ and $P v u$ II. The arrows indicate partially digested fragments.

Telmatobiinae and Paratelmatobius to the Leptodactylinae subfamily.

The monophyly of Leptodactylinae and Telmatobiinae (sensu Duellman and Trueb, 1986) was already refuted in a study by Ruvinsky and Maxson (1996), in which Eleutherodactylus cuneatus (currently allocated to the Eleutherodactylinae subfamily) was the representative of Telmatobiinae, and Lithodytes lineatus the representative of Leptodactylinae. In that paper, the results also suggested Leptodactylidae polyphyly.

On the other hand, if we consider the current classification presented by Frost (2002), in which Paratelmatobius and Scythrophrys are allocated together and apart from the

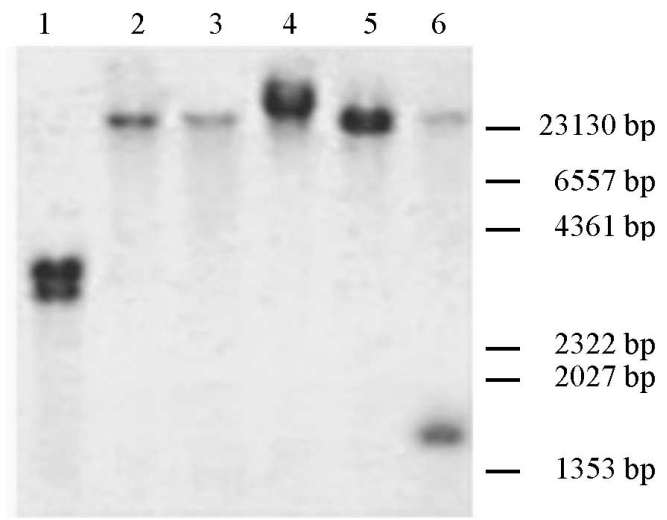

Figure 6 - Southern blotting of the genomic DNA of Hylodes asper (1), Paratelmatobius poecilogaster (2), P. cardosoi (3), Paratelmatobius sp (aff. cardosoi) (4), Scythrophrys from Rancho Queimado (5), and Scythrophrys of group I from Piraquara (6), after digestion with $P v u$ II and hybridization with the pBS 28 probe.

Leptodactylinae and Telmatobiinae species, our results do not confront with the hypothesis brought by Hillis and Davis (1987). So, although a study including various Leptodactylidae genera and several characters is necessary for a conclusive analysis of their taxonomy and intergeneric relationships, our results suggest that an investigation of the Bst EII site in the 28S gene may be useful.

The other informative region was the additional $P v u$ II site found in the two group I Scythrophrys populations, which was absent in the Scythrophrys specimens from Rancho Queimado, in the Paratelmatobius species, and in other anurans of this study and others (Hillis and Davis, 1987). Since intraspecific variation in the $28 \mathrm{~S}$ gene is not common (see Hillis and Dixon, 1991), and the existence of two species in the genus Scythrophrys has already been proposed based on studies of the same populations sampled here (Lourenço et al., in press), it is possible that the variation in the Pvu II restriction site described above represents an interspecific divergence.

It is also interesting to note that there was no intraindividual variability in $P$. poecilogaster, despite the two NOR-bearing chromosome pairs in this karyotype (chromosome pairs 8 and 10; Lourenço et al., 2000). Moreover, all the species studied, as well as the individuals from the two group I Scythrophrys populations, could be distinguished from each other by the size of the digested fragments. This finding and the restriction site variation discussed above suggest that sequencing of the rDNA segment focused in this study could provide useful data for phylogenetic studies of Paratelmatobius and Scythrophrys.

\section{Acknowledgments}

The authors thank Dr. Anete Pereira de Souza for helping with the subcloning experiments, Dr. Wanderley Dias da Silveira for important suggestions, and FAPESP (Foundation for the Support of Research of the State of São 
Paulo) for financial support (Proc. 97/00459-9 and 98/06087-9).

\section{References}

Arnheim N (1983) Concerted evolution of multi-gene families. In: Nei M and Koehn RK (eds.) Evolution of genes and proteins. Sinauer, Sunderland, pp 38-61.

Arnheim N, Treco D, Taylor B and Eicher E (1980) Distribution of ribosomal gene length variants among mouse chromosomes. Proc Natl Acad Sci USA 79:4677-4680.

Coen E, Strachan T and Dover G (1982a) Dynamics of concerted evolution of ribosomal DNA and histone gene families in the melanogaster species subgroup of Drosophila. J Mol Biol 158:17-35.

Coen E, Thoday JM and Dover G (1982b) Rate of turnover of structural variants in the rDNA gene family of Drosophila melanogaster. Nature 295:564-568.

Dover GA and Coen E (1981) Springcleaning ribosomal DNA: a model for multigene evolution? Nature 290:731-732.

Duellman WE and Trueb L (1986) Biology of amphibians. McGraw-Hill, New York, 670 pp.

Frost DR (2000) Amphibian species of the world: an online reference. V. 2.20 (1 September 2000). Electronic database available at http://research.amnh.org/herpetology/amphibia/ index.html.

Frost DR (2002) Amphibian species of the world: an online reference. V. 2.21 (15 July 2002). Electronic database available at http://research.amnh.org/herpetology/amphibia/index. html.

Garcia PCA (1996) Recaracterização de Scythrophrys sawayae (Cochran, 1953) baseada em morfologia, osteologia e aspectos da miologia e história natural (Amphibia: Leptodactylidae). Masters dissertation, PUCRS, Porto Alegre, Brazil.

Heyer WR (1975) A preliminary analysis of the intergeneric relationships of the frog family Leptodactylidae. Smith Contr Zool 199:1-55.
Hillis DM and Davis SK (1987) Evolution of the 28S ribosomal RNA gene in anurans: regions of variability and their phylogenetic implications. Mol Biol Evol 4:117-125.

Hillis DM and Dixon MT (1991) Ribosomal DNA: molecular evolution and phylogenetic inference. Quart Rev Biol 66:411-453.

Krystal M, D’Eustachio P, Ruddle FH and Arnheim N (1981) Human nucleolus organizers on nonhomologous chromosomes can share the same ribosomal gene variants. Proc Natl Acad Sci USA 78:5744-5748.

Long EO and Dawid IB (1980) Repeated genes in eukaryotes. Annu Rev Biochem 49:727-764.

Lourenço LB, Garcia PCA and Recco-Pimentel SM (2000) Cytogenetics of two species of Paratelmatobius (Anura: Leptodactylidae), with phylogenetic comments. Hereditas 133:201-209.

Lourenço LB, Garcia PCA and Recco-Pimentel SM (in press) Intrageneric karyotypic divergence in Scythrophrys and new insights into the relationship with Paratelmatobius (Anura, Leptodactylidae). Ital J Zool 70.

Lourenço LB, Garcia PCA and Recco-Pimentel SM (2003) Cytogenetics of a new species of Paratelmatobius cardosoi group (Anura: Leptodactylidae), with the description of an apparent case of pericentric inversion. Amphibia-Reptilia 24:47-55.

Lynch JD (1971) Evolutionary relationships, osteology, and zoogeography of leptodactyloid frogs. Univ Kans Mus Nat Hist, Misc Publ 53:1-238.

Meunier-Rotival M, Cortadas J, Macaya G and Bernardi G (1979) Isolation and organization of calf ribosomal DNA. Nucl Acids Res 6:2109-2123.

Miller OL (1981) The nucleolus, chromosomes and visualization of genetic activity. J Cell Biol 91:15-17.

Ruvinsky I and Maxson LM (1996) Phylogenetic relationships among bufonoid frogs (Anura: Neobatrachia) inferred from mitochondrial DNA sequences. Mol Phylogenet Evol 5:533-547.

Sambrook J, Fritsch EF and Maniatis T (1989) Molecular cloning. A laboratory manual. $2^{\text {nd }}$ edition. Cold Spring Harbor Press.

Editor: Yatiyo Yonenaga-Yassuda 